\title{
Researching an Elizabethan Shipwreck: The Gresham Ship Project 2007-2012
}

\author{
Gustav Milne, Dean Sully* and Jens Auer ${ }^{+}$
}

In 1846 , a protracted underwater excavation took place in the Thames Estuary, some $11 \mathrm{~km}$ north-north-east of Margate, Kent. The focus of this pioneering project was an ancient shipwreck, but the objective was simply to salvage as much of its valuable, if prosaic, cargo as possible. The historic significance of the discovery was not completely overlooked, however, for at a meeting of the British Archaeological Association in December of that year, a handful of items recovered from the wreck were discussed (Anon, 1847). They included a tin ingot stamped with the royal mark (a rose surmounted by a crown); a knife with a double fleur-de-lis stamped on the blade; a roundtoed leather shoe and a silk doublet of late 16th-century type. To accompany the display, the following note was read:

It had been known long since there was a wreck on the Girdler Sand (off Herne Bay) but no one took any notice of it, not knowing what wreck it was, until this spring when divers went down and examined and recovered some iron guns, of very ancient date, also some of those curious ingots and some iron, lead in pigs and red lead in cast iron casks, covered with wood. ... At the date of this letter, however, the operations were being conducted under the orders of the Duke of Wel-

\footnotetext{
UCL Institute of Archaeology, London WC1H OPY, United Kingdom g.milne@ucl.ac.uk,d.sully@ucl.ac.uk University of Southern Denmark Niels Bohrs Vej 9, DK-6700 Esbjerg, Denmark auer@hist.sdu.dk
}

lington, as Lord Warden of the Cinque Ports, and the men had then recovered about 2,700 of the ingots, and more iron, pig lead, red lead, together with some stone shot. (Anon, 1847: 361-362)

A provisional assessment of the material recovered suggested a 16th-century date for the ship. However, once sufficient metalwork had been recovered and recycled, interest in the site waned and the precise location lost.

That was until the Port of London Authority (PLA) began clearance work in the Princes Channel in 2003, to facilitate the passage of modern shipping heading into the new Thames Gateway container port, when the remains of the Elizabethan ship were dramatically rediscovered. A second underwater excavation project then began, but this time, 150 years later, with rather different aims and technologies. Maritime archaeologists from Wessex Archaeology, led by Jens Auer (now Assistant Professor of Archaeology at the University of Southern Denmark), were called in to evaluate and record the hull remains and associated artefacts. Iron bars, ingots of lead and tin, pottery and leather were also recovered, together with four guns, one of which had the grasshopper and ' $T G$ ' insignia on the barrel. This is the mark of Thomas Gresham (1519-79): the famous London financier, merchant and gunfounder. Further confirmation of an Elizabethan date for the ship was provided by an assessment of twelve dendrochronological samples from the hull timbers, suggesting that the timbers were felled in England in 1574 (Auer and Firth, 2007: 224). 


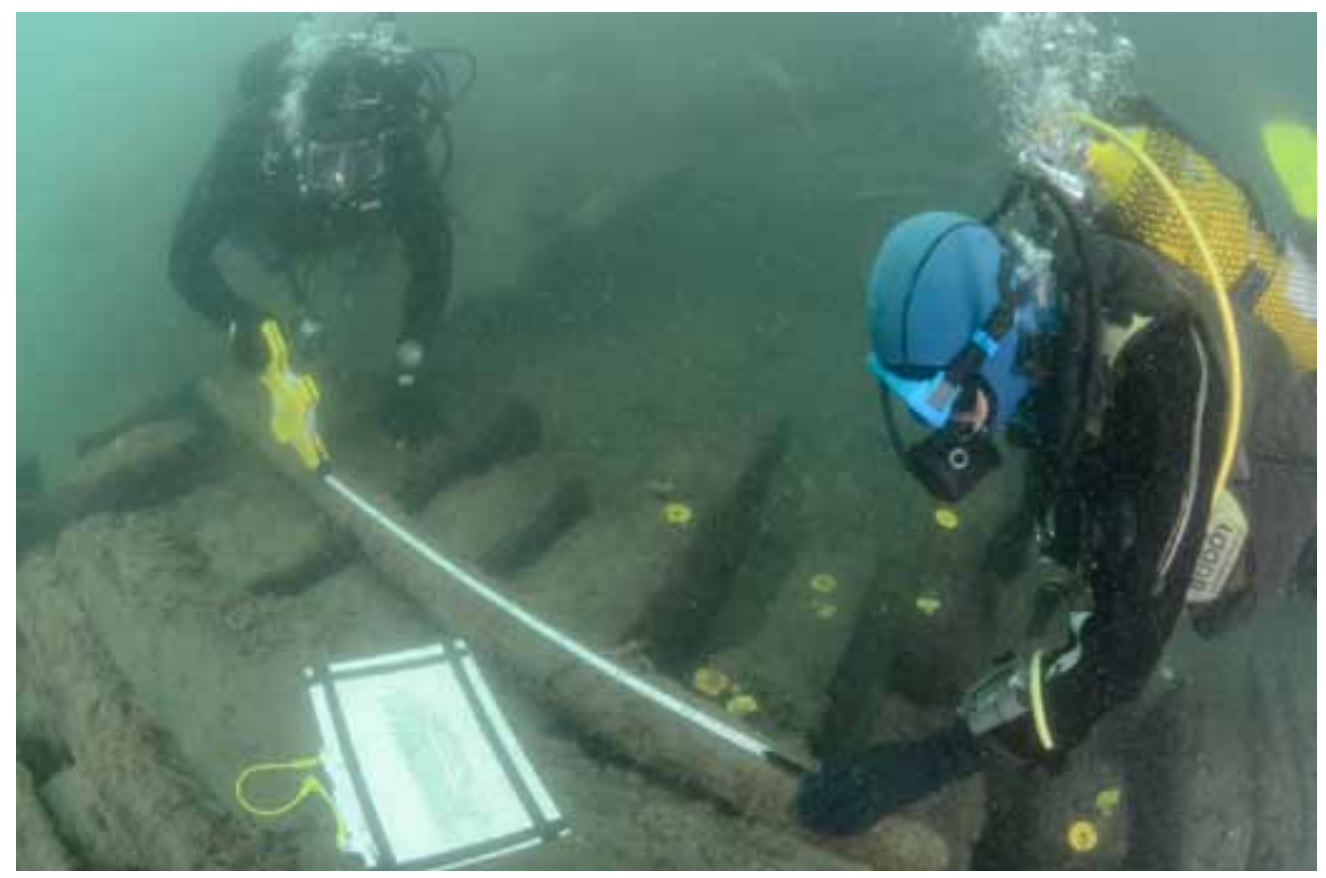

Fig. 1: Recording the Gresham Ship (photo Mark Beattie Edwards/Nautical Archaeology Society).

Once the fieldwork in the Thames estuary was complete, the five substantial sections of the hull raised from the sea bed were temporarily transferred to Horsea Lake in Hampshire, while deliberations began as to how such an important but unexpected find should be dealt with. Appreciating the unique significance of the discovery for nautical archaeology, as well as for London and the long history of its port, the PLA generously agreed to support an innovative 5-year research programme. Studies of the hull and the ships contents were to be integrated into carefully co-ordinated graduate teaching and dissertation programmes, so that Masters students would be provided with real, relevant hands-on experience to complement and extend their lecture-based studies. The project was co-ordinated at UCL, given the Institute of Archaeology's long association with maritime archaeology, with the Nautical Archaeology Society and with the study of London.

Work commenced in 2007, when a steering group was set up to oversee the programme, chaired by Professor Clive Orton, with representation from the PLA (Gill Andrews), the Receiver of Wreck (Alison Kentuck), the Nautical Archaeology Society (Mark Beattie Edwards), the Museum of London (Hazel Forsyth and Roy Stephenson) and Gresham College (Geoff Pavitt), as well as from the University of Southern Denmark and UCL.

\section{Hull studies}

Research on the detailed records of the five substantial sections of the vessel itself were conducted at the University of Southern Denmark, using computers and 1:10 scale models, through a series of graduate projects supervised by Jens Auer. These studies show that the vessel was of about 160 tons, $24.5 \mathrm{~m}$ in length, with a keel length of $19 \mathrm{~m}$, and an internal width (beam) of $7.4 \mathrm{~m}$. The hold was some $3.4 \mathrm{~m}$ deep, and the hull was strongly framed with integral gunports (Thomsen, 2010; Alexiou, 2011; Ni Chiobhain, 2011). It seems clear that the vessel was reworked during its initial construction to increase the beam and capacity of the hull, a process later 
referred to as 'furring' (Wagstaffe, 2010); this is the first time that such a procedure has been identified archaeologically.

Although the largest vessels of this period were twice this size, the Gresham Ship would not have been considered as a small ship. It was, for example, broadly the same size as the Golden Hind, which successfully circumnavigated the globe in 1577-80. It is known that at least fifteen vessels of a similar size were built in London and the East coast region from 1574-7 (Oppenheim, 1896: 172174) and thus our ship should be seen as a typical, hard-working, armed merchantman of this era.

\section{Cargo and concretions}

The majority of the finds assemblage (Fig. 2) was transferred to UCL in April 2009 from the English Heritage facility at Fort Cumberland, Hampshire. The work then focused on investigative conservation revealing the contents of twenty-two marine concretions (extensive deposits that develop around artefacts on the sea bed), followed by the stabilisation of the resulting artefacts. This work was supervised by Dean Sully, with notable contributions by Kelly Domoney, Libby McCormick and other UCL graduates working in the Conservation Laboratories. One of the largest concretions contained a powder chamber (Fig. 2), representing a fourth gun, while painstaking work on another revealed part of a gun carriage. Other significant (but rather smaller) finds that have now been cleaned, processed and conserved include ceramics, a pewter salt-holder, a silver spoon (Fig. 2), a copper-alloy dish and leather footwear, including part of a seaman's boot.

Meanwhile, Marcos Martinón-Torres supervised the analysis of the cargo metals. The tin ingots appear to be of English origin, but the lead ingots and some of the iron are more likely to have originated in Sweden. This particular type of bar iron, which is folded so as to be transportable by packhorse, is also referred to as 'slave iron', given that it was sometimes used as currency exchanged for slaves from West Africa in the 17th century (Birch, 2009).
The guns are currently in the care of the Royal Armouries at Fort Nelson, undergoing a long desalination treatment supervised by their curator, Phil Magrath.

\section{Public outreach and the UCL Museum Studies MA}

With generous support from Gresham College, a series of public lectures on aspects of the Tudor Port of London was held, together with a full-day conference in the Museum of London in Docklands. This was supported by a major display put together by a team of UCL's Museum Studies MA students as part of their course-work, under the direction of Theano Moussouri and Ian Carroll (but led by Victoria Kinahan), with additional funding from the Mercers' Company.

In May 2012, the hull timbers were transported from Hampshire to Leicestershire, becoming a major exhibit in the National Dive Centre at Stoney Cove. This ensures that the remains are in a secure but accessible location, forming part of a major new underwater heritage attraction and a facility used by the Nautical Archaeological Society to train the next generation of maritime archaeologists. The finds from the ship will be transferred to the care of the Southend Museum Service. They will be displayed in a brand new museum building overlooking the estuary, in a purpose-built gallery with a theme focussed on wrecks from the Thames.

\section{Final report}

The research conducted at UCL and at USD is being brought together in two volumes, to be published in the Nautical Archaeology Society's monograph series. The first volume will deal with the vessel itself, the second considers its contents and sets the discoveries in a wider context:

Auer, J (ed.) (in prep.) An Armed Elizabethan Merchantman from the Thames Estuary: vol. 1. Hull Studies.

Milne, G and Sully, D (eds) (in prep.) An Armed Elizabethan Merchantman from the Thames Estuary: vol. 2. Cargo \& Contents. 


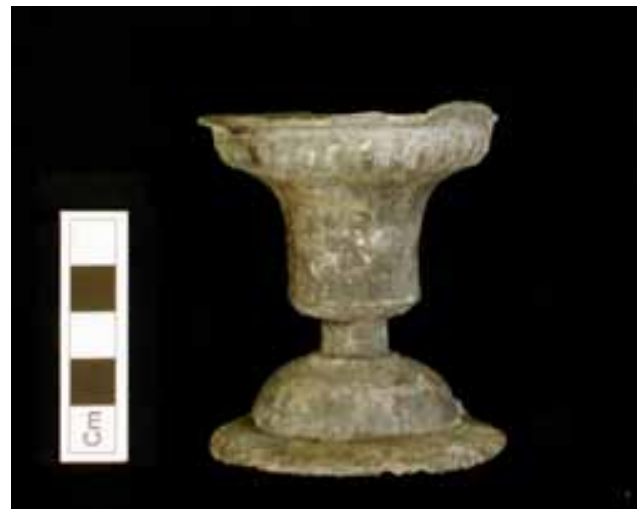

Tin-alloy salt stand (14)

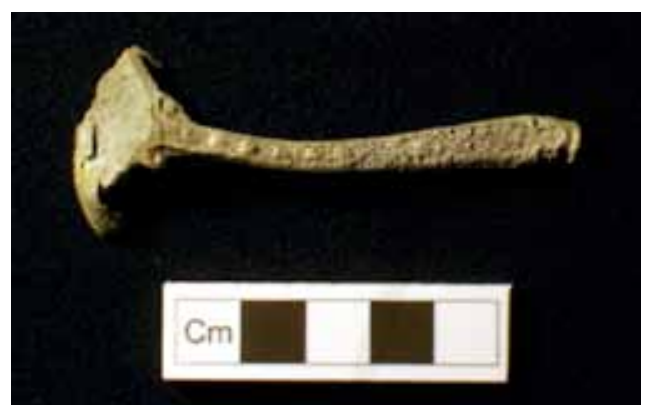

Tin-alloy spoon (86.7)

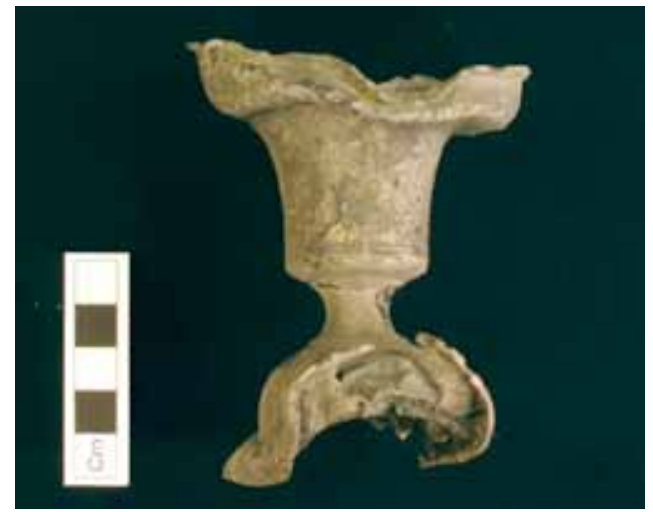

Tin-alloy salt stand (86.1)

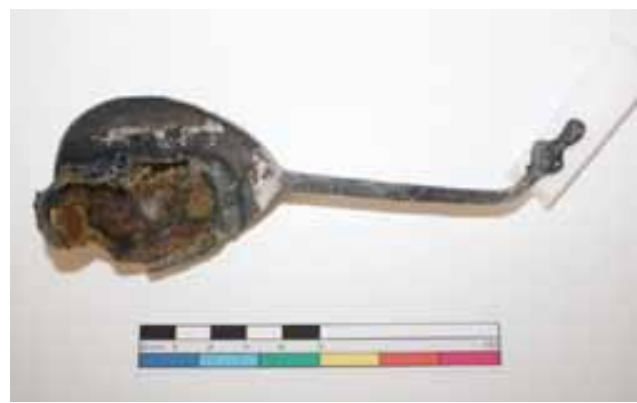

Silver spoon, with ceramic fragment (20.1)

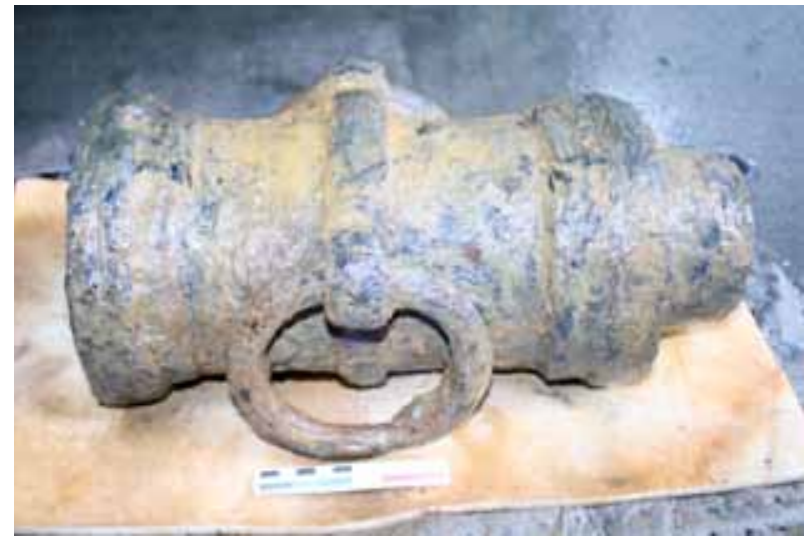

Powder chamber (202.1)

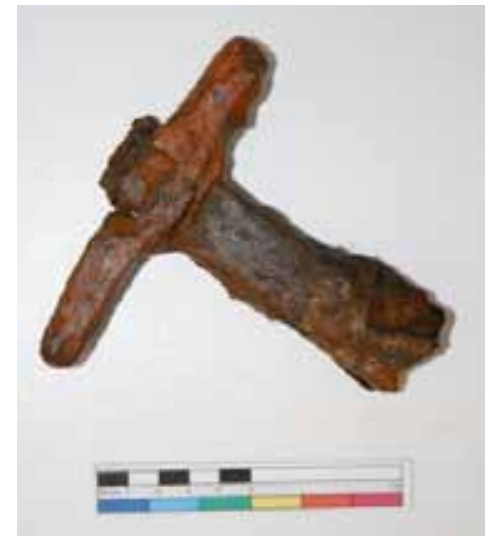

Hammer fragment (202.2)

Fig. 2: Selection of finds from the Gresham Ship assemblage.

This 5-year research programme has thrown new light on ship-building and gun founding, on traffic and trade, and on the port of London in the age of Drake, Frobisher and Raleigh. This was a period when armed merchantman, like the Gresham Ship, would have been opening up new trade routes, exploring new worlds, circumnavigating the globe or taking on the Spanish Armada. For good or for ill, such ships and their redoubtable crews were the making of Elizabethan England. 


\section{References}

Anon 1847 Proceedings of the Association. Journal of the British Archaeological Association 2: 361-362.

Auer, J and Frith, A 2007 The Gresham Ship: an interim report on a 16th-century wreck from the Princes Channel, Thames Estuary. Journal of Post-Medieval Archaeology 41/2: 222-241. DOI: http://dx.doi. org/10.1179/174581307X318967.

Oppenheim, M 1896 A History of the Administration of the Royal Navy 1509-1660. London.

\section{Gresham Ship Project Research Reports: UCL/English Heritage}

Birch, T 2009 The Gresham Ship: an investigation into the iron bars. Unpublished MSc dissertation in Archaeology, UCL.

Booth, J 2009 Conservator Agency and Maritime Archaeology. Unpublished MA dissertation in Principles of Conservation, UCL.

Domoney, K 2007 Managing the Maritime Cultural Heritage: a conservation perspective. Unpublished MA dissertation in Principles of Conservation, UCL.

Domoney, K 2009 Conservation Plan for Processing Concretions: investigation, documentation and stabilisation. The Gresham Ship Project Internship: Conservation Technical Reports.

Domoney, K 2009/10 Preliminary Conservation of Finds from the Gresham Ship Project. English Heritage Research Reports.
Domoney, K 2011 Gresham Ship: Princes Channel, Thames Estuary: conservation of an Elizabethan shipwreck assemblage. (English Heritage Research Dept Report Series no. 102-2009.

Hanson, K 2008 The Shoe and the Shipwreck Artefact. Unpublished MA dissertation in Principles of Conservation, UCL.

Smith, K 2008 Conserving Cannons: case studies in raising the profile of maritime archaeology. Unpublished MA dissertation in Principles of Conservation, UCL.

Smith, K 2009 Case Study: the boot from the Gresham Ship Project. Unpublished MSc dissertation in Conservation for Archaeology and Museums, UCL.

Gresham Ship Project Research Reports: University of Southern Denmark (USD)

Alexiou, K 2011 Two 16th Century-Ships: their hull form and performance. Unpublished MA dissertation in Maritime Archaeology, USD.

Ni Chiobhain, D 2011 The Arming of Late 16th Century Merchantmen. Unpublished MA dissertation in Maritime Archaeology, USD.

Thomsen, C 2010 Reconstructing the Lines of the Princes Channel Ship. Unpublished MA dissertation in Maritime Archaeology, USD.

Wagstaffe, C 2010 'Furring' in the Light of 16th-Century Ship Design. Unpublished MA dissertation in Maritime Archaeology, USD. 